\title{
Christine Schneider
}

Kirche und Kolleg der Jesuiten in Dillingen an der Donau. Regensburg: Schnell \& Steiner, 2014. Pp. 432. Hb, 86 Euros.

This is a remarkable book, richly illustrated and packed with information. Those of us who have visited the Jesuit college and church in Dillingen will appreciate the hundreds of illustrations (most of which we must have missed), while those who have not had the opportunity to make a personal inspection will be even more grateful. Dillingen an der Donau may not be a household name, at least outside of Germany, but many will know that quite early on in the Society of Jesus's history (1563), the first Jesuit university on German soil was established in that city. During the second third of the eighteenth century, the order (by then well-established and wealthy) decorated the church and college with the program of images with which this book is largely concerned. But it would be difficult to write anything about the Jesuits without at some point dealing with politics and the Counter-Reformation.

The present volume is a detailed presentation of the construction of a complex of buildings-including the university, the Jesuit college, and the church - along with their decorations. In this effort, Christine Schneider draws on a wealth of earlier documentation. The book has three parts and an appendix of color reproductions (341-426). The first part, called simply "A," on "Dokumentation," brings together information on sources (19-25), history $(27-52)$ and a visual description of church and college (53-59). The second part, "B," is entitled "Formgeschichtliche und ikonografische Untersuchungen" [Investigations of Form and Iconography" (63-287), and is divided into separate sections on the church and college. The final part, "C," deals with the ideas behind the buildings' decorative scheme ("Ideengeschichtliche Überlegungen" [Considerations from a History of Ideas], 291-314).

It would be impossible in a review to do justice to the author's use of her many sources. Dillingen was caught up in the religious conflicts between Protestants and Catholics, and was home to a college even before the Jesuits arrived. Indeed, there had long been controversy between the Catholic bishopric and the town of Dillingen. Nor were the German universities exempt from such religious feuding. It may be difficult for the modern reader to appreciate how tense such difficulties could be. Especially Americans are used to notions of freedom of speech, freedom of religion, freedom of assembly, but these are new freedoms that may today have to be curtailed somewhat in a new age of terrorism. The University of Tübingen had gone over to Protestantism in 1534; already in 1527 , an evangelical university had been founded in Marburg. Naming a new bishop for Augsburg in the early sixteenth century was as much 
a political as a religious act. The new bishop, the twenty-nine-year-old jurist Otto Truchseß von Waldburg, was already an old hand in such political and religious questions (27). It appears that he used some of his own wealth in furthering the building initiatives (32), and he evidently required the Catholic bishopric to fund the building and maintenance of both college and university (33) - though he himself was not a Jesuit. The Jesuits took over the existing college, the Collegium Sancti Hieronymi (31-32), and in only three years built the first Jesuit college, which the community occupied in 1568 (33). In 1732, the Society forced ("forcierte") the physical expansion of the college (38).

Much space is understandably taken up with discussions of the construction specifically of the Jesuit church, given that students of the college were required to attend church services regularly. To today's viewer, the most salient result of the renovation of the church in the 175 os was the creation of frescoes and illustrations (40-41). The university and its various buildings are also discussed, as well as a further section on the artists involved (47-52). In the descriptions of the Jesuit church and college buildings (53-59) and their decorations (69-75), Schneider demonstrates a keen and insightful eye, especially in the discussion of the ceiling paintings (86-90).

There is perhaps a slight danger in attaching too great a weight to the decorative program of this one site and reading into it something of the central concerns of Ignatius and the Jesuits. Of course, there can be no doubt of the importance of Ignatius himself, his early companions, and the first Jesuit saints. Nor can we question the centrality of the Virgin Mary in the spirituality of Ignatius himself, as has been made abundantly clear in the doctoral study by Louis A. Bonacci, S.J., entitled The Marian Presence in the Life and Works of Ignatius Loyola (Dayton: Marian Library / International Marian Research Institute, the University of Dayton, Ohio, U.S.A., 2002). But the extent to which Marian piety dominated the Jesuits' subsequent endeavors is debatable. This is not to deny Mary's importance or to forget the order's many Marian sodalities throughout the world. Bonacci's study may well appear to support Schneider's position (92-97). But the centrality of the Virgin Mary, dominant though it is in many of the Dillingen paintings, is not borne out by the Ratio studiorum, the flexible blueprint for Jesuit education worldwide.

Who is likely to form the book's audience? Jesuits, obviously; anyone concerned with the history of Dillingen will appreciate the volume's detail; but even those less interested in the city itself will find insights into the role of the Society, as well as some perhaps unexpected details on non-Jesuit stakeholders.

It is well known that the rulers of Munich, the Witttelsbach dynasty, supported the Society of Jesus, towards the ultimate goal of the re-Catholicization of Europe, as well as the introduction of the faith on other continents. It is 
therefore no accident that Dillingen in Bavaria was regarded by the order as of central importance.

Interest in the various activities of the Society of Jesus in Europe and across the world appear to have increased, and also among non-Jesuits. A recent conference at the University of Wisconsin, Madison in 2013, organized by Sabine Mödersheim, addressed the topic of the contribution of Jesuit scientists to the growth of science in the earlier modern period. Professor Mödersheim hopes to publish the conference proceedings.

As I have pointed out, the volume is richly illustrated, with ninety-one numbered images throughout the text and a block of 165 colored plates at the end (341-426). Perhaps a small quibble will be allowed. The captions to the illustrations are informative, especially with regard to the artists. Likewise, it was helpful to be told which images were engravings and which woodcuts. But oddly missing, when the illustration came from a printed book, was the expected information on author, title, publisher and date. Perhaps if there is a new edition or re-issue this can be remedied.

I think that I would be remiss if I did not admit that reading a folio-sized book of over 400 pages in German is a challenge. The effort is certainly worth the investment in time- - after all, the book derives from a dissertation at the University of Freiburg (Winter semester 2010). The dates suggest that it took the years 2010 to 2014 to produce and print the final work. But with all respect German has never been a world language like Latin was (at least to the intelligentsia in the early modern period everywhere and later), and then French and now English. Many scholars in China and Japan often make the products of their research also available in English, at least for the moment. I ask myself how many scholars and students are going to read this German book. Or will it be another book with seven (or more) seals for non-Germans? Particularly troubling is the absence of translations of Latin in this book, although I realize that this has nothing to do with the scholarship of the book, or the usefulness of the numerous illustrations, for which we must all be grateful. Clearly the author assumes that her reader has little or no difficulty with Latin. I would no longer make that assumption, which was common though it was in earlier scholarship.

To conclude on a positive note: this book deserves to be in any library, anywhere in the world, which contains studies of the Society of Jesus, art history, or emblems.

\section{Peter M. Daly}

McGill University, Montreal, Canada

peter.daly@mcgill.ca

DOI $10.1163 / 22141332-00203005-14$ 